\title{
Historein
}

Vol 4 (2003)

Public Histories

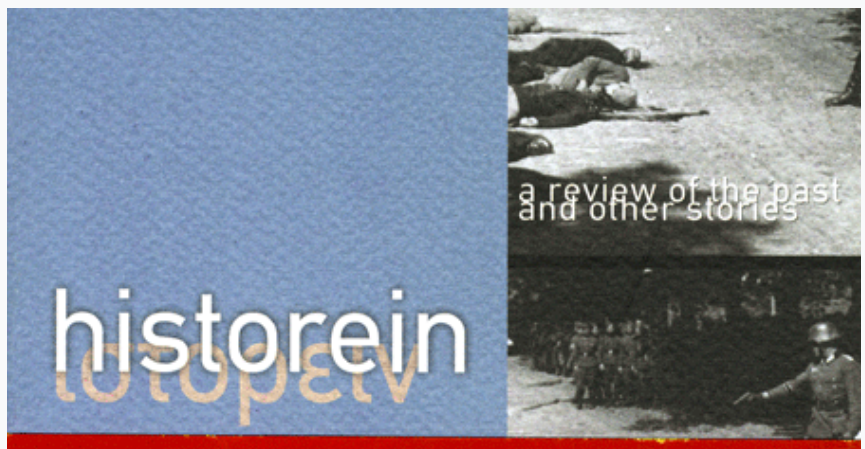

\section{Philippos Iliou (1931-2004)}

\section{Historein Historein}

doi: $\underline{10.12681 / \text { historein.94 }}$

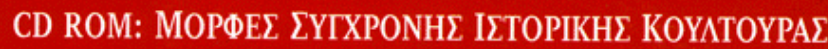

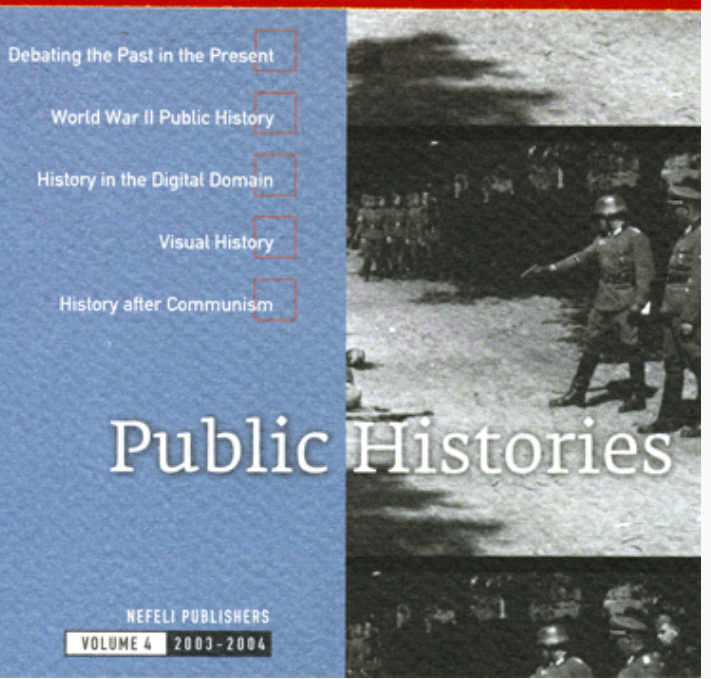

Copyright @ 2012, Historein Historein

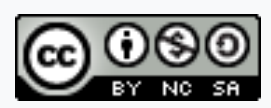

This work is licensed under a Creative Commons Attribution-NonCommercialShareAlike 4.0.

\section{To cite this article:}

Historein, H. (2004). Philippos Iliou (1931-2004). Historein, 4, 230. https://doi.org/10.12681/historein.94 


\section{Philippos Iliou (1931-2004)}

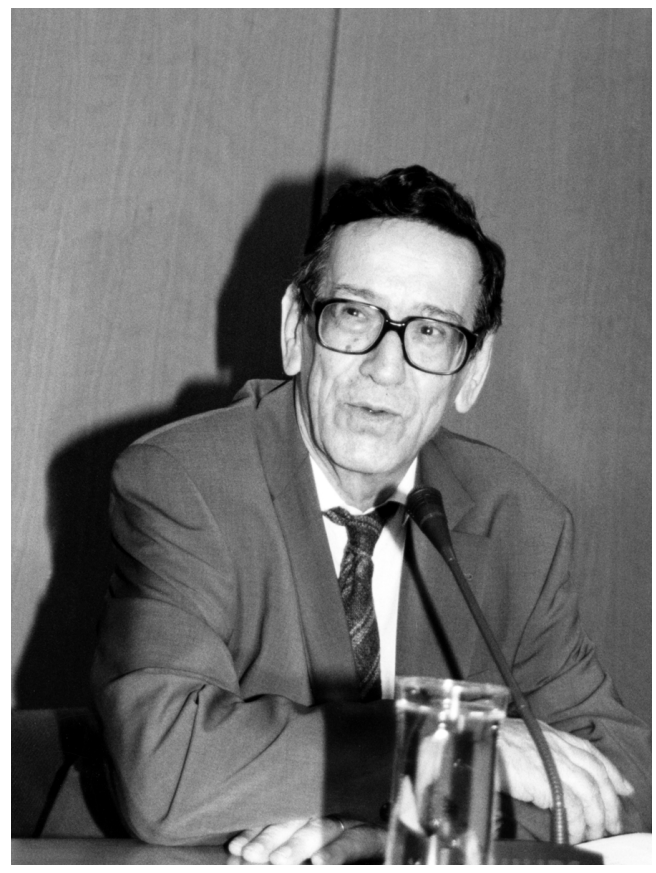

The distinguished Greek historian Philippos Iliou passed away on March 5, 2004. Widely known as one of the most prominent historians and intellectuals of the postwar era, Philippos Iliou, a notorious hard-worker and an original thinker, has left behind an important and pioneering body of works primarily focusing on the history of the Greek Enlightenment, the history of the Left in modern and contemporary Greece together with his lengthy research on the Greek book production. Iliou played a key role in the shaping of the historical discipline and community in Greece after the fall of the dictatorship (1974) by initializing and constantly contributing in the publication of the scholarly journal Ta lotopıká (Historica) and in the establishment of the Archives of Contemporary Social History. An eternally energetic, humorous and deeply sensitive person, Philippos Iliou was also an important public figure with a strong commitment to the politics of the Left. His interventions, not to the least reduced by his illness until the very end, were always marked by sharp insight and moral clarity. Historein shares the grief for the loss of a great historian and friend and pays tribute to his agency in the making of contemporary historiography and history. 